\title{
METODIČKI PRISTUPI OBRADI LEKTIRE U PRVOM RAZREDU OSNOVNE ŠKOLE: IZAZOV ZA POTICANJE I RAZVIJANJE ČITATELJSKIH KOMPETENCIJA
}

\begin{abstract}
APSTRAKT: Jedna je od temeljnih zadaća nastave Hrvatskoga jezika u osnovnoj školi razvijanje čitateljskih navika. Istraživanja već duže vrijeme ukazuju na opći pad interesa za knjigu, a lektira postaje nužno sredstvo približavanja čitanja učeniku. Učitelji svojim načinima rada i metodičkim pristupima mogu znatno utjecati na učenike i njihovu kulturu čitanja. Cilj je rada doprinijeti struci istraživanjem o učiteljskim metodičkim pristupima u obradi lektire u prvom razredu osnovne škole. Istraživanjem je obuhvaćeno 89 učitelja Splitsko-dalmatinske županije i Grada Zagreba. Anketnim upitnikom su prikupljeni podatci u skladu s navedenim ciljem i problemima istraživanja. Rezultati istraživanja pokazali su da učitelji teže suvremenijim metodičkim pristupima u obradi lektire kojima nastoje poticati razvijanje čitateljskih kompetencija.
\end{abstract}

Ključne riječi: nastava Hrvatskoga jezika, razredna nastava, školska lektira, učiteljski metodički pristupi, čitateljske kompetencije.

\section{METHODICAL APPROACHES TO MANDATORY READING IN THE FIRST GRADE OF ELEMENTARY SCHOOL: A CHALLENGE FOR ENCOURAGING AND DEVELOPING READING COMPETENCES}

SUMMARY: One of the basic tasks of Croatian language education in elementary school is to develop the readers' habits. Teachers, through their methods and methodical approaches, can substantially influence students and their reading culture. The research into the teachers' methodical approaches to mandatory reading classes in the first grade of elementary school includes 89 teachers of the Split-Dalmatia County and the City of Zagreb. The aim of the paper is to explore the teaching methods and methodical approaches to mandatory reading in the first grade of elementary school. A survey questionnaire was developed as a research tool that collected the data in accordance with the objective and research issues. The results of the research have shown that the teachers opt for more contemporary methodical approaches to mandatory reading classes to encourage the development of reading competences.

Keywords: Croatian language education, primary school education, mandatory reading, teachers' methodical approaches, reading competences. 


\section{UVOD}

Istraživanja o „krizi čitanja“ nisu nov problem, no intenziviraju se pojavom novih medija i novih tehnologija. Učenici postaju nezainteresirani za knjige, a roditelji i učitelji nisu naročito zadovoljni hrvatskim obrazovnim sustavom. Pozitivan pomak je uočavanje problema te, u skladu s tim, pokušaj provođenja (još uvijek nejasno određenih) promjena u obrazovnom sustavu. Nacionalna strategija promicanja čitanja započela je 2017. godine, a Cjelovita kurikulna reforma kreće u eksperimentalni program od školske godine 2018./2019. Stručnjaci, odgojitelji, knjižničari i mnogi drugi nastoje ponovno pobuditi interes djece i mladih za čitanje. Usprkos tome, jača strah od toga da će knjiga postupno nestati iz čitateljske kulture. U radu se suočavamo s problematikom čitanja u svijetu i u Hrvatskoj, obuhvaćajući teme specifičnosti početnoga čitanja, čitateljske pismenosti i čitateljskih kompetencija te primjene poticajnih metodičkih pristupa u obradi lektire.

Nastojalo se doprinijeti struci istraživanjem o učiteljskim metodičkim pristupima u obradi lektire u prvom razredu osnovne škole koje obuhvaća učitelje ${ }^{1}$ Splitsko-dalmatinske županije i grada Zagreba. Cilj je istraživanja ispitati načine rada učitelja, odnosno metodičke pristupe koje koriste pri obradi lektire u prvom razredu osnovne škole kada se dijete prvi put susreće s pojmom lektire i suočava s potrebom sustavnog čitanja, sa svojevrsnom obvezom čitanja, što zahtijeva posebno brižan i oprezan pristup učitelja želi li se postići krajnji cilj - pozitivan odnos prema knjizi.

Pristupi obradi lektire poznati su u metodičkoj teoriji, a u skladu sa zahtjevima vremena proširuju se neprestano kreativnim prijedlozima. Ostaje, međutim, još nedovoljno istraženo koliko učitelji primjenjuju suvremene metodičke prijedloge $i$, ako ih primjenjuju, uspijevaju li realizirati postavljeni cilj - poticati $i$ razvijati čitateljske kompetencije učenika.

\section{SPECIFIČNOSTI POČETNOGA ČITANJA}

Čitanje je jedna od složenijih mentalnih aktivnosti i vještina koju je „važno usvojiti u dječjoj dobi jer se na njoj temelji u velikoj mjeri djetetova spoznaja svijeta i mogućnost budućega profesionalnoga osposobljavanja“ (ČudinaObradović, 2014: 9). Potvrda teze o čitanju kao jednoj od složenijih mentalnih aktivnosti vidljiva je iz definicije čitanja (Peti-Stantić, 2009: 7):

Čitanje je neurološka sposobnost, povezana s onim što nas oblikuje kao ljudska bića, vještina koja proizlazi iz specifičnosti pisma kao jednoga od najznačajnijih civilizacijskih dostignuća u povijesti ljudskog roda, pomaknuto, produženo i prošireno sporazumijevanje, povezano s onim što nas oblikuje kao društvena bića, spoznavanje kulture kao prostora discipline i prostora slobode, povezano s onim što

${ }^{1}$ Označava osobe muškoga i ženskoga spola. 
nas oblikuje kao misaona bića sposobna pojmiti intelektualni napor kao uzbudljiv čin.

Ono što razlikuje materinski govor (urođen i instinktivan) od čitanja je činjenica da ne postoji posebni živčani mehanizam koji bi omogućio nesvjesno i automatsko usvajanje čitanja. Podatci koji se rabe pri čitanju moraju se obrađivati u dijelu mozga koji je zadužen za govor. To znači da je za čitanje potrebno da mozak prvo pretvori pisanu riječ u glasove jer govorni sustav može primati samo glasovni oblik podataka. Na primjer, kada u sebi čitamo, ne možemo pročitati riječ, a da je prvo u sebi ne izgovorimo. Zato je čitanje složena vještina i znamo da se mora učiti. Za osobu možemo reći da zna (zrelo) čitati kada ima ispunjene sljedeće preduvjete: ima razvijenu fonemsku svjesnost, može dekodirati, tečno čita, ima razvijen rječnik i dobro razumije ono što pročita (Čudina-Obradović, 2014).

$\mathrm{Na}$ početku prvoga razreda učitelji se susreću s djecom međusobno vrlo različitih sposobnosti i predznanja. Puljak (2007) smatra da su prvoškolci najneujednačenija obrazovna skupina koja se može zamisliti. To potvrđuje i autoričino istraživanje koje pokazuje da sva djeca prvoga razreda nisu još funkcionalno zrela da bi mogla naučiti čitati. Zato je jedan od prvih zadataka učitelja provesti ispitivanje predznanja učenika. Potrebno je utvrditi predznanje svakoga učenika kako bi učitelj mogao individualizirati pristup poučavanju početnoga čitanja i pisanja i tako omogućio razvoj čitateljske pismenosti na temelju individualnih karakteristika i potreba učenika (Puljak, 2001). Osim predznanja, učitelji trebaju prepoznati što djeca žele čitati i prema tome izabrati primjerene metodičke pristupe i literarne sadržaje (Lučić-Mumlek, 2002).

\section{3. ČITATELJSKA PISMENOST I ČITATELJSKE KOMPETENCIJE}

Pismenost se u prošlom stoljeću definirala kao znanja i vještine čitanja, pisanja i računanja, ali društvene promjene utjecale su na promjenu toga koncepta te se pokazalo da nije više dovoljno znati samo čitati, pisati i računati. Najnovije shvaćanje pismenosti podrazumijeva višedimenzionalnost i složenost (UNESCO, 2004: 12):

Pismenost je sposobnost prepoznavanja, razumijevanja, interpretiranja, stvaranja, komuniciranja i računanja koristeći se ispisanim ili pisanim materijalima povezanima u različitim kontekstima. Pismenost uključuje neprekinuti slijed učenja kako bi se pojedincu omogućilo da ostvari svoje ciljeve, razvije znanja i sposobnosti i da potpuno sudjeluje u svojoj zajednici i širem društvu.

Proteklih godina Hrvatska sudjeluje u velikom međunarodnom programu za procjenu znanja i vještina učenika (PISA istraživanje) kojim se ispituje do koje su razine mladi ljudi u dobi od petnaest godina stekli ključne kompetencije i koliko su pripremljeni za nastavak školovanja i život u odrasloj dobi. Ključne kompetencije koje se utvrđuju proizlaze iz područja čitateljske, matematičke i prirodoslovne pismenosti. Zbog važnih ciljeva i obilježja PISA je pokazatelj kvalitete školskih sustava i obrazovnih politika. Istraživanja su pokazala značajnu povezanost između 
postignuća učenika u čitateljskoj pismenosti i njihova kasnijeg uspjeha na tržištu rada (Braš Roth i sur., 2010). Budući da se vremena mijenjaju, čitateljska se pismenost promatra i tumači na drugačiji način te se javlja potreba za novim, suvremenijim kompetencijama. Danas se pod konceptom čitateljske pismenosti podrazumijeva sposobnost pojedinca da samostalno pronađe podatke i informacije, koristi se njima, razumije ih, promišlja o njima i zauzima kritički stav: „Čitalačka pismenost je razumijevanje, korištenje, promišljanje $\mathrm{i}$ angažman $u$ pisanim tekstovima radi postizanja osobnih ciljeva, razvoja vlastita znanja i potencijala te aktivnog sudjelovanja u društvu." (Braš Roth i sur., 2010: 36). Osim toga, čitateljska pismenost uključuje čitateljske kompetencije pronalaženja, odabira, tumačenja i vrednovanja informacija i podataka iz različitih tekstova u stvarnim, autentičnim životnim situacijama (Braš Roth i sur., 2010).

Posljednje istraživanje $\mathrm{u}$ sklopu ciklusa PISA najviše usmjereno na čitateljsku pismenost bilo je ono iz 2009. godine. Posebno zabrinjava činjenica da su hrvatski učenici ostvarili ispodprosječna postignuća iz čitateljske pismenosti. Osim procjene znanja i vještina gotovo 5000 učenika, istraživanje je uključivalo i anketiranje učenika, roditelja i školskih ravnatelja. Anketiranjem hrvatskih učenika više od jedne četvrtine njih izjavilo je da je čitanje gubitak vremena i da nikada ne čita iz zadovoljstva, više od pola hrvatskih učenika tvrdi da čita samo kako bi pronašlo određenu informaciju, ne voli ići u knjižnicu niti dobiti knjigu na poklon (Braš Roth i sur., 2010). S obzirom na opći pad interesa za knjigu, postizanje zadovoljavajuće razine čitateljske pismenosti postaje stručni i znanstveni izazov. Razlog pada interesa za knjigu i čitanje najčešće nalazimo u pojavi novih medija $i$ tehnologija, što je samo djelomično točno. Mnogi se stručnjaci slažu s tim da mladi i dalje čitaju, ali su se sadržaj i medij preko kojega čitaju značajno promijenili, što posljedično utječe na kvalitetu čitanja. Problem je uočen u činjenici da se ne čita kvalitetno i s razumijevanjem, već se tekst prelijeće većom brzinom i usvaja se znatno veći broj informacija nego što je to bilo prije pojave interneta. Prema Grosman (2010), razloge za nedovoljno razvijenu čitateljsku pismenost kod mladih treba tražiti u neprikladnim metodama kojima učitelji poučavaju. Istraživanjem PISA iz 2000. godine uočeno je da postoji veća korelacija između postignutog rezultata u čitateljskoj pismenosti i čitateljskog angažmana. Čitateljska pismenost ne podrazumijeva samo znanja i sposobnosti, već i čitateljski angažman (motivaciju, stavove i određena ponašanja) koji ,podrazumijeva način na koji učenici percipiraju podršku koju dobivaju od nastavnika, razreda i škole za njihova motivacijska obilježja i bihevioralne karakteristike u čitanju“ (Braš Roth i sur., 2010: 68). Dakle, ako učenik dobiva podršku od osoba koje su mu važne (u obiteljskom i školskom okruženju) i ako mu se na taj način pruža osjećaj samopouzdanja i autonomije u čitanju, učenik postaje intrinzično motiviran za čitanje, čitanje mu postaje važno, a postupno se stvara i ljubav prema čitanju; ,,̌to učenici više čitaju, to su bolji čitači, a što bolje čitaju i više očekuju dobro postignuće u čitalačkoj pismenosti, to više vole čitati“" (Braš Roth i sur., 2010: 66). 


\section{METODIČKI SUSTAVI I PRISTUPI U NASTAVI KNJŽEVNOSTI}

Općeprihvatljivu raščlambu metodičkih sustava nastave književnosti uspostavio je Dragutin Rosandić (1986, 2005). Metodičke sustave nazvao je dogmatsko-reproduktivnim, reproduktivno-eksplikativnim, interpretativnoanalitičkim, problemsko-stvaralačkim i korelacijsko-integracijskim. Bežen (2005) je pojednostavnio nazive metodičkih sustava i zadržao samo prvi izraz u nazivu. Prema Beženu (2008) metodički sustav podrazumijeva primjenu određenih metoda, postupaka, oblika nastave te nastavnih sredstava i izvora. Nastava Hrvatskoga jezika podijeljena je na nekoliko područja (početno čitanje i pisanje, jezik, književnost, jezično izražavanje i medijska kultura), stoga se i metodički sustavi razlikuju prema određenim područjima.

Metodički sustav najčešće prisutan u nastavi Hrvatskoga jezika jest interpretativno-analitički. Njegov naziv ukazuje na cilj - pobuditi učenikove doživljaje o književnom djelu; učitelj i učenik zajedno tumače književno djelo. Književno djelo je jezična umjetnina, a upoznavanje s njim je doživljajni i spoznajni proces. Učitelj ima ulogu organizatora nastavnoga procesa, a ne ulogu predavača. Metode karakteristične za ovaj sustav su metoda razgovora i metoda rada na tekstu. Problemski sustav postaje sve poželjniji metodički sustav u svijetu, ali i u Hrvatskoj, učitelj organizira problemsku situaciju i postavlja probleme učenicima, a učenici samostalno trebaju riješiti zadani problem. Učenici se kritički odnose prema književnom djelu i raspravljaju s učiteljem o rezultatima, a dominiraju istraživačka i raspravljačka metoda. Dobra strana ovoga sustava je mogućnost supostojanja većeg broja različitih rješenja, a to znači da svaki učenik može riješiti problem na svoj način (originalnost je jedna od temeljnih značajki kreativnosti). Najčešći oblik rada je individualni rad. Sustav o kojem se često govorilo proteklo desetljeće jest korelacijsko-integracijski sustav. Korelacija znači povezivanje nastavnih sadržaja unutar predmeta i među predmetima. To znači da se obrada književnoga djela povezuje i sa sadržajima jezika, jezičnoga izražavanja, medijske kulture i/ili drugih predmeta što je u razrednoj nastavi, u odnosu na predmetnu, znatno lakše ostvariti.

Težak (1996) predlaže, a uvidjelo se i nastavnom praksom, da se metodički sustavi ne moraju dosljedno i isključivo primjenjivati. To znači da se sustavi najčešće isprepliću i nadopunjuju tako da jedan sat Hrvatskoga jezika može biti i najčešće jest kombinacija nekoliko metodičkih sustava. Kada se koncepcija kojega sustava primjenjuje samo u jednom dijelu nastavnoga sata, a u drugim dijelovima sata se primjenjuje koncepcija drugih sustava, tada govorimo o metodičkom pristupu (Težak, 1996). Metodički sustavi su na raspolaganju učitelju da ih kombinira i služi se njima na svakom satu Hrvatskoga jezika kako bi na što kvalitetniji način ostvario cilj sata. Lazzarich (2017) naglašava kako je važno mijenjati pristup obradi književnih djela kako bi se izbjegla monotonija, pogotovo u nastavi lektire koja bi trebala učenicima biti poticajna i uzbudljiva. Važno je kombinirati metodičke sustave i pristupe u skladu s interesima, specifičnostima i potrebama učenika. 


\section{CILJ, PROBLEMI I METODOLOGIJA ISTRAŽIVANJA}

Cilj istraživanja bio je ispitati načine rada učitelja, odnosno metodičke pristupe koje koriste pri obradi lektire u prvom razredu osnovne škole. U skladu s navedenim ciljem postavljeni su sljedeći problemi istraživanja:

1. ispitati povezanost između učiteljskih pristupa i stavova o obradi lektire u prvom razredu osnovne škole i učiteljskih očekivanja od učenika na satima lektire tijekom prvoga razreda osnovne škole;

2. ispitati smatraju li učitelji da njihov pristup obradi lektire potiče razvijanje čitateljskih kompetencija;

3. ispitati na koji način učitelji motiviraju učenike za književnoumjetničko djelo.

Podatci su prikupljeni anketnim upitnikom koji se sastoji od pitanja otvorenoga tipa i tvrdnji u obliku Likertove ljestvice utvrđivanja stavova.

Anketa je provedena tijekom travnja, svibnja i lipnja 2018. godine u devet osnovnih škola Splitsko-dalmatinske županije i tri osnovne škole grada Zagreba. Prije popunjavanja upitnika sudionici su bili upoznati sa svrhom ispitivanja i činjenicom da je ispitivanje anonimno. Ukupno je 89 ispunjenih upitnika koji su uvršteni u analizu podataka obrađenih deskriptivnom i kvantitativnom metodom.

Anketni upitnik obrađen je u cijelosti deskriptivnom metodom. Dio ankete koji se procjenjivao Likertovom ljestvicom procjene prvo se izračunao parametrima deskriptivne statistike: aritmetičkom sredinom (AS), standardnom devijacijom (SD), $95 \%$ intervalom pouzdanosti aritmetičke sredine $( \pm 95 \% \mathrm{IP})$, minimalnim rezultatom (Min), maksimalnim rezultatom (Maks) i testnom vrijednosti KolmogorovSmirnovljeva testa (MaxD) te značajnost KS testa (KSp). Zatim je dodatno obrađen kvanitativnom metodom kanoničke korelacijske analize čije ćemo rezultate tek kratko iznijeti bez detaljnog tabličnog prikaza. Pitanja otvorenoga tipa procjenjivala su se parametrima deskriptivne statistike. Svi podatci obrađeni su korištenjem softvera za računalnu obradu podataka Statistica 13.0. (Dell Inc., Tulsa, Oklahoma, SAD).

\section{REZULTATI ISTRAŽIVANJA}

Vezano za prvi problem istraživanja 29 je promatranih i ispitanih varijabli, a podijeljene su u dva dijela. U Tablici 1 nalaze se rezultati deskriptivne statistike za promatrane varijable v1-v15, a u Tablici 2 nalaze se varijable v16-v29. Varijable (v1v15) označuju izjave o učiteljskim metodičkim pristupima i stavovima pri obradi lektire u prvom razredu osnovne škole, a varijable (v16-v29) označuju učiteljska očekivanja od učenika na satima lektire u prvom razredu osnovne škole. U statističkoj obradi podataka aritmetička sredina (AS) predstavlja težište rezultata, a standardna devijacija (SD) pokazuje mjeru rasipanja rezultata (Bubić, 2015). Aritmetička sredina bolje reprezentira dobivene rezultate ako je standardna devijacija manja, jer se oni u 
prosjeku manje razlikuju od nje. Standardna devijacija za sve promatrane varijable kreće se u rasponu od 0,33 do 1,29 , što znači da je relativno niska. KolmogorovSmirnovljev test (KSp) služi za provjeru normaliteta distribucije (Bubić, 2015). Sve varijable (v1-v29) imaju narušen normalitet distribucije jer je $\mathrm{p}<0,01$, jedino (v21) ima $\mathrm{p}<0,05$. Za sve navedene varijable izračunati su sljedeći parametri: aritmetička sredina (AS), standardna devijacija (SD), 95\% interval pouzdanosti aritmetičke sredine $( \pm 95 \%$ IP), minimalni rezultat (Min), maksimalni rezultat (Maks), testna vrijednost Kolmogorov-Smirnovljeva testa (MaxD) i značajnost KS testa (KSp).

\begin{tabular}{|c|c|c|c|c|c|c|c|}
\hline Varijabla & $\mathbf{A S} \pm \mathbf{S D}$ & $-95 \%$ IP & $+95 \% \mathrm{IP}$ & Min & Maks & MaxD & KSp \\
\hline $\begin{array}{l}\text { v1. Učenici u središtu nastavnoga } \\
\text { procesa }\end{array}$ & $4,73 \pm 0,54$ & 4,59 & 4,87 & 3,00 & 5,00 & 0,47 & $\mathrm{p}<0,01$ \\
\hline v2. Suradničko učenje & $4,78 \pm 0,46$ & 4,66 & 4,89 & 3,00 & 5,00 & 0,48 & $\mathrm{p}<0,01$ \\
\hline $\begin{array}{l}\text { v3. Razvijanje učeničkih } \\
\text { čitateljskih kompetencija }\end{array}$ & $3,95 \pm 0,68$ & 3,78 & 4,12 & 2,00 & 5,00 & 0,31 & $\mathrm{p}<0,01$ \\
\hline $\begin{array}{l}\text { v4. Postavljanje problemske } \\
\text { situacije }\end{array}$ & $4,48 \pm 0,67$ & 4,31 & 4,64 & 3,00 & 5,00 & 0,35 & $\mathrm{p}<0,01$ \\
\hline $\begin{array}{l}\text { v5. Učestalost pružanja gotovih } \\
\text { rješenja }\end{array}$ & $1,65 \pm 0,72$ & 1,47 & 1,83 & 1,00 & 4,00 & 0,29 & $\mathrm{p}<0,01$ \\
\hline $\begin{array}{l}\text { v6. Pružanje zadataka s više } \\
\text { različitih rješenja }\end{array}$ & $3,81 \pm 1,00$ & 3,56 & 4,06 & 1,00 & 5,00 & 0,29 & $\mathrm{p}<0,01$ \\
\hline $\begin{array}{l}\text { v7. Razvijanje čitateljskih } \\
\text { kompetencija jedino čitanjem } \\
\text { školske lektire }\end{array}$ & $2,63 \pm 1,26$ & 2,32 & 2,95 & 1,00 & 5,00 & 0,21 & $\mathrm{p}<0,01$ \\
\hline $\begin{array}{l}\text { v8. Učestalost služenja istim } \\
\text { nastavnim metodama }\end{array}$ & $2,51 \pm 1,29$ & 2,18 & 2,83 & 1,00 & 5,00 & 0,23 & $\mathrm{p}<0,01$ \\
\hline v9. Učitelj kao organizator & $1,97 \pm 1,02$ & 1,71 & 2,22 & 1,00 & 4,00 & 0,26 & $\mathrm{p}<0,01$ \\
\hline $\begin{array}{l}\text { v10. Uporaba metodičke } \\
\text { literature i stručno usavršavanje }\end{array}$ & $4,43 \pm 0,64$ & 4,27 & 4,59 & 3,00 & 5,00 & 0,32 & $\mathrm{p}<0,01$ \\
\hline $\begin{array}{l}\text { v11. Kombiniranje modernih i } \\
\text { tradicionalnih metoda }\end{array}$ & $4,40 \pm 0,66$ & 4,23 & 4,56 & 2,00 & 5,00 & 0,30 & $\mathrm{p}<0,01$ \\
\hline $\begin{array}{l}\text { v12. Važnost da učenici zavole } \\
\text { čitanje }\end{array}$ & $4,92 \pm 0,33$ & 4,84 & 5,00 & 3,00 & 5,00 & 0,53 & $\mathrm{p}<0,01$ \\
\hline $\begin{array}{l}\text { v13. Učenici kao pasivni } \\
\text { slušatelji }\end{array}$ & $1,16 \pm 0,60$ & 1,01 & 1,31 & 1,00 & 5,00 & 0,51 & $\mathrm{p}<0,01$ \\
\hline $\begin{array}{l}\text { v14. Oslanjanje na praktično } \\
\text { iskustvo }\end{array}$ & $3,22 \pm 1,11$ & 2,94 & 3,50 & 1,00 & 5,00 & 0,27 & $\mathrm{p}<0,01$ \\
\hline $\begin{array}{l}\text { v15. Popis lektire odgovara } \\
\text { učeničkim interesima }\end{array}$ & $3,10 \pm 0,96$ & 2,85 & 3,34 & 1,00 & 5,00 & 0,22 & $\mathrm{p}<0,01$ \\
\hline
\end{tabular}

Tablica 1. Parametri deskriptivne statistike za varijable povezane s učiteljskim metodičkim pristupima $^{2}$

${ }^{2}$ Legenda: v1. Učenici u središtu nastavnoga procesa (Smatram da učenici trebaju biti u središtu nastavnoga procesa); v2. Suradničko učenje (Potičem učenike na suradničko učenje); v3. Razvijanje učeničkih čitateljskih kompetencija (Smatram da se sadašnjim pristupom obrade lektire dovoljno razvijaju učeničke čitateljske kompetencije); v4. Postavljanje problemske situacije (Često postavljam problemske situacije kao izazov 
Promatranjem aritmetičke sredine v12 (Jedan od ciljeva koji mi je važan je da učenici zavole čitanje) potvrđuje se da je učiteljima važno da učenici zavole čitanje. No, pozitivni učiteljski stavovi i očekivanja ne znače nužno usklađenost $\mathrm{s}$ nastavnom praksom. Nadalje, aritmetičke sredine v1 (Smatram da učenici trebaju biti u središtu nastavnoga procesa) i v2 (Potičem učenike na suradničko učenje) pokazuju da učitelji dosljedno imaju stav da učenik treba biti aktivan sudionik nastavnoga procesa, a to znači da je zadaća učitelja navesti učenika da pita, raspravlja, istražuje, zahtijeva, surađuje s učiteljem rješavajući zadane i stvarne probleme (Težak, 1996). Također, učitelji izjavljuju da potiču učenike na suradničko učenje, što znači da nastavu provode „radom u malim, suradničkim skupinama sastavljenima od učenika različitih akademskih postignuća te po mogućnosti različitog spola i različitih rasa povezanih zajedničkim ciljem sa svrhom ovladavanja određenim akademskim sadržajem“ (Reić-Ercegovac, Jukić, 2008: 69).

Shodno tomu, aritmetičke sredine v9 (Više sam predavač, nego organizator nastavnoga procesa) i v13 (Smatram da učenici trebaju biti pasivni slušatelji) potvrđuju da većina učitelja smatra da su i sami više organizatori nastavnoga procesa nego predavači, te se slažu s tim da učenici ne trebaju biti pasivni slušatelji. No, odgovori su raspodijeljeni od minimalne vrijednosti (uopće se ne slažem) do maksimalne vrijednosti (u potpunosti se slažem), što znači da neki učitelji smatraju da su više predavači i da učenici trebaju biti pasivni slušatelji. Varijable koje propituju učiteljsku primjenu problemskoga pristupa u nastavi su v4 (Često postavljam problemske situacije kao izazov učenicima), v5 (Često dajem učenicima gotova rješenja) i v6 (Postavljam učenicima zadatke koji mogu imati više različitih rješenja). Učitelji se djelomično slažu da često postavljaju problemske situacije učenicima, izjavljuju da rijetko daju učenicima gotova rješenja, a većina njih izjasnila se ocjenom 3 o tome postavljaju li učenicima zadatke koji mogu imati više različitih rješenja.

učenicima); v5. Učestalost pružanja gotovih rješenja (Često dajem učenicima gotova rješenja); v6. Pružanje zadataka s više različitih rješenja (Postavljam učenicima zadatke koji mogu imati više različitih rješenja); v7. Razvijanje čitateljskih kompetencija jedino čitanjem školske lektire (Smatram da učenici jedino čitanjem školske lektire mogu razvijati čitateljske kompetencije); v8. Učestalost služenja istim nastavnim metodama (Rijetko mijenjam nastavne metode, često na sličan način obrađujem lektiru); v9. Učitelj kao organizator (Više sam predavač, nego organizator nastavnoga procesa); v10. Uporaba metodičke literature i stručno usavršavanje (Pratim metodičku literaturu i stručno se usavršavam); v11. Kombiniranje modernih i tradicionalnih metoda (Kombiniram moderne $i$ tradicionalne metode); v12.Važnost da učenici zavole čitanje (Jedan od ciljeva koji mi je važan je da učenici zavole čitanje); v13. Učenici kao pasivni slušatelji (Smatram da učenici trebaju biti pasivni slušatelji); v14. Oslanjanje na praktično iskustvo (Oslanjam se većinom na svoje praktično iskustvo); v15. Popis lektire odgovara učeničkim interesima (Smatram da sadašnji popis lektira u Nastavnom planu i programu odgovara učeničkim interesima). 
Također, istraživanjem je ispitano služe li se učitelji često istim nastavnim metodama (v8 - Rijetko mijenjam nastavne metode, često na sličan način obrađujem lektiru) ili kombiniraju tradicionalne i moderne metode (v11 Kombiniram moderne i tradicionalne metode). Aritmetičke sredine potvrđuju da se učitelji djelomično ne slažu da rijetko mijenjaju nastavne metode i djelomično se slažu da kombiniraju moderne i tradicionalne metode. S druge strane, ispitano je i u kojoj mjeri učitelji prate metodičku literaturu i usavršavaju li se formalno u području vlastite struke (odlaze li na seminare i druge oblike usavršavanja) (v10) te u kojoj mjeri se oslanjaju na svoje praktično iskustvo (v14). Promatrajući aritmetičku sredinu v10, učitelji se djelomično slažu s izjavom da prate metodičku literaturu i da se stručno usavršavaju, dok su neodlučni oko toga oslanjaju li se većinom na svoje praktično iskustvo (v14). Razmatrajući odgovore koji se tiču stava o razvijanju čitateljskih kompetencija (v3 - Smatram da se sadašnjim pristupom obrade lektire dovoljno razvijaju učeničke čitateljske kompetencije) učitelji su neodlučni ili se djelomično slažu da općenito sadašnji pristup obradi lektire dovoljno razvija čitateljske kompetencije. Također, učitelji se djelomično ne slažu s izjavom da učenici jedino čitanjem školske lektire mogu razvijati čitateljske kompetencije (v7). Zanimljivi su rezultati aritmetičke sredine stava o sadašnjem popisu lektira (v15 - Smatram da sadašnji popis lektira u Nastavnom planu $i$ programu odgovara učeničkim interesima). Učitelji su prosječno neodlučni o tome odgovara li sadašnji popis lektira učeničkim interesima. Štoviše, odgovori se kreću na Likertovoj ljestvici od 1 do 5, što nam pokazuje da se neki učitelji u potpunosti slažu s tim da sadašnji popis lektira odgovara učeničkim interesima, ali i da ima onih koji se uopće ne slažu s navedenom izjavom.

\begin{tabular}{|c|c|c|c|c|c|c|c|}
\hline Varijabla & $\mathbf{A S} \pm \mathbf{S D}$ & $-95 \%$ IP & $+95 \%$ IP & Min & Maks & MaxD & KSp \\
\hline $\begin{array}{l}\text { v16. Slušanje i razumijevanje } \\
\text { književnoumjetničke } \\
\text { riječi }\end{array}$ & $3,92 \pm 0,83$ & 3,71 & 4,13 & 2,00 & 5,00 & 0,22 & $\mathrm{p}<0,01$ \\
\hline $\begin{array}{l}\text { v17. Samostalno čitanje } \\
\text { lektire u drugom } \\
\text { polugodištu prvoga razreda }\end{array}$ & $3,63 \pm 1,07$ & 3,37 & 3,90 & 1,00 & 5,00 & 0,25 & $\mathrm{p}<0,01$ \\
\hline $\begin{array}{l}\text { v18. Primanje i literarni } \\
\text { doživljaj knj. djela }\end{array}$ & $3,87 \pm 0,77$ & 3,68 & 4,07 & 2,00 & 5,00 & 0,23 & $\mathrm{p}<0,01$ \\
\hline $\begin{array}{l}\text { v19. Reproduciranje } \\
\text { činjenica i sudova }\end{array}$ & $3,54 \pm 0,91$ & 3,31 & 3,77 & 1,00 & 5,00 & 0,26 & $\mathrm{p}<0,01$ \\
\hline $\begin{array}{l}\text { v20. Pamćenje detalja o } \\
\text { knj. djelu }\end{array}$ & $3,43 \pm 0,98$ & 3,18 & 3,68 & 1,00 & 5,00 & 0,29 & $\mathrm{p}<0,01$ \\
\hline $\begin{array}{l}\text { v21. Prepričavanje knj. } \\
\text { djela svojim riječima }\end{array}$ & $3,65 \pm 1,21$ & 3,35 & 3,95 & 1,00 & 5,00 & 0,20 & $\mathrm{p}<0,05$ \\
\hline $\begin{array}{l}\text { v22. Iznošenje svoga } \\
\text { doživljaja i razmišljanja o } \\
\text { knj. djelu }\end{array}$ & $4,13 \pm 0,98$ & 3,88 & 4,37 & 1,00 & 5,00 & 0,27 & $\mathrm{p}<0,01$ \\
\hline $\begin{array}{l}\text { v23. Rješavanje problema u } \\
\text { problemskim situacijama }\end{array}$ & $4,02 \pm 0,66$ & 3,85 & 4,18 & 2,00 & 5,00 & 0,32 & $\mathrm{p}<0,01$ \\
\hline
\end{tabular}




\begin{tabular}{lccccccc}
$\begin{array}{l}\text { v24. Komuniciranje i } \\
\text { raspravljanje o problemu u } \\
\text { knj. djelu }\end{array}$ & $4,10 \pm 0,76$ & 3,90 & 4,29 & 2,00 & 5,00 & 0,28 & $\mathrm{p}<0,01$ \\
\hline $\begin{array}{l}\text { v25. Kritičko mišljenje i } \\
\text { slobodno iznošenje svojih } \\
\text { sudova o knj. djelu }\end{array}$ & $4,22 \pm 0,89$ & 4,00 & 4,45 & 1,00 & 5,00 & 0,25 & $\mathrm{p}<0,01$ \\
\hline $\begin{array}{l}\text { v26. Rješavanje } \\
\text { stvaralačkoga zadatka }\end{array}$ & $3,97 \pm 0,74$ & 3,78 & 4,15 & 2,00 & 5,00 & 0,29 & $\mathrm{p}<0,01$ \\
\hline $\begin{array}{l}\text { v27. Vođenje dnevnika } \\
\text { čitanja po ustaljenom } \\
\text { obrascu. }\end{array}$ & $2,52 \pm 1,27$ & 2,20 & 2,84 & 1,00 & 5,00 & 0,23 & $\mathrm{p}<, 01$ \\
\hline $\begin{array}{l}\text { v28. Unaprjeđivanje } \\
\text { čitačkih i komunikacijskih } \\
\text { vještina }\end{array}$ & $4,43 \pm 0,56$ & 4,29 & 4,57 & 3,00 & 5,00 & 0,32 & $\mathrm{p}<0,01$ \\
\hline $\begin{array}{l}\text { v29. Stjecanje navike i } \\
\text { potrebe za čitanjem }\end{array}$ & $4,65 \pm 0,48$ & 4,53 & 4,77 & 4,00 & 5,00 & 0,42 & $\mathrm{p}<0,01$
\end{tabular}

Tablica 2. Parametri deskriptivne statistike za varijable povezane s učiteljskim očekivanjima od učenika ${ }^{3}$

Varijable v16 (Očekujem da slušaju, ali i razumiju književnoumjetničku riječ), v18 (Očekujem da prime i literarno dožive književnoumjetničko djelo), v21 (Očekujem da prepričavaju književnoumjetničko djelo svojim riječima), v22 (Očekujem da iznesu svoj doživljaj i razmišljanja o književnoumjetničkom djelu) i v25 (Očekujem da kritički misle $i$ slobodno iznesu svoje sudove o

\footnotetext{
${ }^{3}$ Legenda: v16. Slušanje i razumijevanje književnoumjetničke riječi (Očekujem da slušaju, ali $i$ razumiju književnoumjetničku riječ); v17. Samostalno čitanje lektire u drugom polugodištu prvoga razreda (Očekujem da počinju samostalno čitati lektiru u drugom polugodištu prvoga razreda); v18. Primanje i literarni doživljaj knj. djela (Očekujem da prime i literarno dožive književnoumjetničko djelo); v19. Reproduciranje činjenica i sudova (Očekujem da reproduciraju činjenice i sudove koje čuju i pročitaju); v20. Pamćenje detalja o knj. djelu (Očekujem da zapamte što više detalja o književnoumjetničkom djelu); v21. Prepričavanje knj. djela svojim riječima (Očekujem da prepričavaju književnoumjetničko djelo svojim riječima); v22. Iznošenje svoga doživljaja i razmišljanja o knj. djelu (Očekujem da iznesu svoj doživljaj i razmišljanja o književnoumjetničkom djelu); v23. Rješavanje problema u problemskim situacijama (Očekujem da rješavaju probleme u problemskim situacijama koje im postavim); v24. Komuniciranje i raspravljanje o problemu u knj. djelu (Očekujem da međusobno komuniciraju i raspravljaju o problemu u književnoumjetničkom djelu); v25. Kritičko mišljenje i slobodno iznošenje svojih sudova o knj.djelu (Očekujem da kritički misle $i$ slobodno iznesu svoje sudove o književnoumjetničkom djelu); v26. Rješavanje stvaralačkoga zadatka (Očekujem da na satu riješe stvaralački zadatak koji im postavim);v27. Vođenje dnevnika čitanja po ustaljenom obrascu (Očekujem od učenika da vode dnevnik čitanja po ustaljenom obrascu); v28. Unaprjeđivanje čitačkih i komunikacijskih vještina (Očekujem da će unaprijediti vještine čitanja i komunikacijske vještine); v29. Stjecanje navike i potrebe za čitanjem (Očekujem da s vremenom steknu naviku i potrebu za čitanjem).
} 
književnoumjetničkom djelu) pokazuju da učitelji u prosjeku djelomično očekuju da učenici slušaju i razumiju književnoumjetničku riječ, prime, literarno dožive, prepričavaju književnoumjetničko djelo svojim riječima te slobodno iznesu svoj doživljaj, razmišljanja, sudove i kritički promišljaju o književnoumjetničkom djelu. Učitelji najviše očekuju da učenici iznesu svoj doživljaj i razmišljanja o književnoumjetničkom djelu i da kritički misle i slobodno iznesu svoje sudove o književnoumjetničkom djelu. Iako se većinom učitelji slažu da očekuju od učenika kritičko mišljenje i slobodno iznošenje svojih sudova o djelu, zanimljivo je da je maksimalni rezultat kojeg su učitelji iznijeli 5, a minimalni rezultat 1 . To pokazuje da ima učitelja koji se uopće ne slažu s tim očekivanjem. Nasuprot tome, učitelji djelomično očekuju od učenika da reproduciraju činjenice i sudove koje čuju i pročitaju (v19) i neodlučni su o tome očekuju li da učenici zapamte što više detalja o književnoumjetničkom djelu (v20). Što se tiče očekivanja da učenici rješavaju probleme u problemskim situacijama koje im učitelj postavi (v23), međusobno komuniciraju i raspravljaju o problemu u književnoumjetničkom djelu (v24), učitelji se ponovno dosljedno slažu s izjavama. Međutim, prema aritmetičkoj sredini, rezultat kazuje da manje očekuju od učenika da na satu lektire riješe stvaralački zadatak koji im učitelj postavi, iako je to jedan od važnih dijelova nastavnoga sata u nastavi Hrvatskoga jezika. Ispitalo se i očekivanje u svezi $\mathrm{s}$ početkom samostalnoga čitanja lektire u drugom polugodištu prvoga razreda (v17). Zanimljivo je da rezultati pokazuju da su učitelji općenito neodlučni, odnosno niti se slažu niti ne slažu s tim očekivanjem. Isto tako, nastojalo se uvidjeti očekuju li učitelji da učenici vode dnevnik čitanja po ustaljenom obrascu (v27). Većina učitelja potvrdila je kako rijetko očekuje vođenje dnevnika čitanja po ustaljenom obrascu od učenika. Uz sve navedeno, provjerila su se i očekivanja koja se temelje na važnim ciljevima/zadaćama nastave Hrvatskoga jezika prema HNOS-u (v28 Očekujem da će unaprijediti vještine čitanja i komunikacijske vještine; v29 Očekujem da s vremenom steknu naviku $i$ potrebu za čitanjem). Rezultati istraživanja pokazali su da se učitelji većinom slažu s tim očekivanjima.

Rezultati kanoničke analize pokazali su da postoji statistički značajna i visoka povezanost između skupova varijabli učiteljskih stavova o metodičkim pristupima i učiteljskih očekivanja od učenika na satima lektire u prvom razredu osnovne škole. Time smo ispitali prvi problem koji se pokazao povezanim što je izvrstan pokazatelj. To znači da učitelji nastoje biti usklađeni i dosljedni u svojim stavovima o općim metodičkim pristupima s opće postavljenim očekivanjima od učenika koje trebaju ispuniti prema propisanom Nastavnom planu i programu i važnim zadaćama Hrvatskoga jezika.

Drugi problem istraživanja bio je ispitati smatraju li učitelji da njihov pristup obradi lektire potiče razvijanje čitateljskih kompetencija. Grafički prikaz prikazuje sljedeće odgovore (Slika 1): najviše ispitanika (79\%) odgovorilo je da njihov sadašnji pristup obradi lektire potiče razvijanje čitalateljskih kompetencija, $11 \%$ se nije izjasnilo, $8 \%$ izjavilo je da ne znaju ili da djelomično potiče i $2 \%$ 
smatra da njihov pristup obradi lektire ne potiče razvijanje čitateljskih kompetencija.

\section{Potiče li Vaš sadašnji pristup obradi lektire razvijanje čitateljskih kompetencija?}

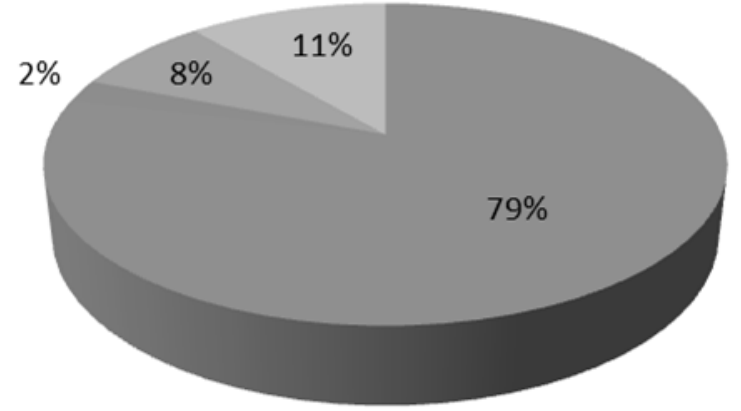

\section{$\mathrm{Da} \square \mathrm{Ne} \square$ Djelomično/ ne znam $\square$ Nije se izjasnilo}

Slika 1. Odgovori učitelja na drugi problem istraživanja

Navedeno problemsko pitanje izazvalo je niz različitih odgovora koji se mogu upotrijebiti u narednim istraživanjima u ovom području:

- „Dobra lektira, zanimljivog i poučnog sadržaja sama je po sebi poticaj za čitanje.“

- „Lektiru obrađujem na različite načine jer smatram da prvi susreti s knjigom uvelike diktiraju razvijanje čitateljskog interesa. Približavanje knjige djetetu osnovna je zadaća lektire u prvim razredima osnovne škole.“

- „Potiče, ali to se ne vidi u prvom razredu, razvija se postupno kroz drugi, treći i četvrti razred, a i to se razlikuje od učenika do učenika, ovisno o interesu za čitanje.“

- „Smatram da ih pristup učitelja potiče na razvijanje čitateljskih kompetencija. Pronađi, usporedi, zaključi...“

- „Pojedini učenici i dalje imaju slabije čitateljske kompetencije, ne vole čitati iako se trudim kombinirati razne metode. Jako vole kad zajedno čitamo.“

- „Mislim da bi se još više postiglo kada bismo lektire prestali provjeravati, kada bismo radili neke projekte, plakate i sl.“

- „Da. Učenici predlažu i ostale priče koje su sami pročitali da se o njima u razredu govori.“ 
- „Mislim da potiče, iako smatram da davanje literature ${ }^{4}$ učenicima nevezano za lektiru (pogotovo učenicima koje to zanima) ima bolji učinak. Mislim da lektira svakako potiče razvoj čitateljskih kompetencija s tim da neki pristupi više pridonose ( $\mathrm{kad}$ je djeci zanimljivo).“

- „Mislim da potiče. Učenicima ne treba davati standardne ispite iz lektire. Treba im dati stvaralačke zadatke."

- „Potičem, organiziram tjedno čitanje. Čitanje traje 20-25 minuta. Preostali dio sata planira se za interpretaciju, razgovor o likovima, likovno stvaralačko izražavanje, osmišljavanje zadataka koji će poticati čitanje.“

- „Potičem, nastojim primjenjivati što više metoda kritičkog mišljenja (dvostruki dnevnik i slično) koje na nenametljiv način utječu na razvoj čitateljskih kompetencija.“

- „Potiče jer su dostupnije informacije u elektroničkim medijima koji motiviraju učenike na sudjelovanje u obradi.“

- „Mislim da da jer ne tražim opširno obrazlaganje čitanja - ne zapisujemo puno, već je naglasak na razvijanju interesa za čitanje i na redovitosti u čitanju. Pokušavam birati naslove zanimljivije učenicima i primjerenije jeziku današnjeg djeteta.“

- „Da, radim prema RWCT modelu.“

- „Potiče, što je obrada lektire zanimljivija, to kod njih stvara ugodu, razvija znatiželju i potiče ih na čitanje.“

- „Da, zainteresiram svako dijete da samostalno čita jer u početku ne forsiram i ne uključujem roditelje. Kući nose na čitanje ono što su neobavezno posudili u školskoj knjižnici. Kasnije svaki učenik želi ispričati o čemu se radi u pročitanoj slikovnici i što mu se svidjelo.“

- „Da, posuđuju više slikovnica, sami osmišljavaju igrokaze i kvizove. Vodimo zajedničke dnevnike čitanja.“

Treći problem istraživanja bio je ispitati na koji način učitelji motiviraju učenike za književnoumjetničko djelo (Slika 2). Najviše učitelja (53\%) izjasnilo se da usmenim putem motivira učenike za književnoumjetničko djelo, zatim igrom (18\%), njih 14\% motivira različitim načinima koji su svrstani u podskupinu Ostalo, vizualnim putem (6\%), postavljanjem problemske situacije (4\%). Jedino se 5\% učitelja od svih ispitanika nije izjasnilo. Zanimljivo je da je većina učitelja naglasila da rabi više različitih oblika motivacije, ali se zbog obrade podataka gledao samo prvi odgovor.

\footnotetext{
${ }^{4}$ Pojam „literatura“ odnosi se na lektiru izvan službenoga popisa.
} 


\section{Kako najčešće motivirate učenike za određeno književnoumjetničko djelo?}

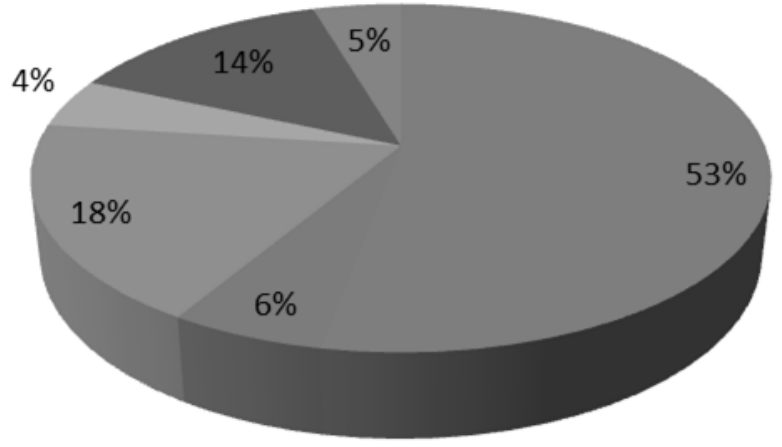

Usmeno

Igrom

Ostalo
- Vizualno

Problemskom situacijom

Nije se izjasnilo

Slika 2. Odgovori učitelja na treći problem istraživanja ispitanika su:

Primjeri odgovora za usmeno motiviranje, o čemu se izjasnila većina

- „Motivacijska priča. Probuđen interes i dobra koncentracija važni su za potpuni doživljaj književnoumjetničkoga djela.“

- „Pitanjima: da si ti glavni lik kako bi se ponašao, kako bi preporučio pročitano svom prijatelju, što bi promijenio da možeš, zašto, kako, kako bi završio radnju, objasni.“"

U podskupini Ostalo (14\%) navedeni su načini motiviranja koji se uvelike podudaraju s drugim navedenim oblicima motivacije:

- „Vođenim čitanjem, problemskim zadatkom, izradom likova (lutke).“

- „Tehnika opuštanja (najčešće) - tehnike koncentracije i uživljavanja koje učenike potiču na pozitivno raspoloženje, izražavanje vlasititih osjećaja i misli.“

- „KWL tablica, oluja ideja, memory, grozdovi, t-tablica, fotografija, kviz, zagonetke, ppt prezentacija, video isječak..."

- „Pohvalnicom za pročitano djelo, ocjenom, usmenom pohvalom za trud, motivacije za čitanje - igre asocijacija...“

- Motiviram ih kroz dramski prikaz.“

- „Gledanje crtanog ili lutkarskog filma snimljenoga po literarnom predlošku; scenska lutka; vođena fantazijska igra, zagonetke o životinjama, čarobna vrećica, itd.“

- „Organiziramo večer čitanja lektire.“ 
- „Pozitivnim stavom o odabranom djelu.“

- „Gluma, izrađivanje od raznih materijala, predstavljanje knjige na razne načine."

Navodimo primjere motiviranja problemskom situacijom: „Postavim im problemsku situaciju vezanu za djelo i pitam ih kako bi to riješili. Onda ih uputim da pročitaju kako je to netko drugi riješio. Ispričam dio priče i pobudim interes za nastavak tako da požele čitati.“

„Zadavanjem nekog problemskog zadatka ili iznošenjem pretpostavke što misle da bi se moglo dogoditi u nastavku.“

\section{ZAKLJUČAK}

Uvidom $\mathrm{u}$ rezultate provedenog istraživanja ispitali smo tri problema vezana za obradu lektire u prvom razredu osnovne škole. Cilj istraživanja bio je ispitati učiteljske načine rada i metodičke pristupe u obradi lektire u prvom razredu osnovne škole.

Prvi problem istraživanja bio je ispitati povezanost između učiteljskih stavova o obradi lektire u prvom razredu osnovne škole i njihovih očekivanja od učenika. Pokazalo se da postoji značajna povezanost između učiteljskih stavova o obradi lektire i učiteljskih očekivanja od učenika. Što se tiče učiteljskih stavova o obradi lektire pokazalo se da je većina učitelja više organizator nastavnoga procesa, nego što su predavači, da potiču suradničko učenje, jedan od ciljeva im je da učenici zavole čitanje, i često učenicima postavljaju problemske situacije. Pri obradi lektire, učitelji najviše očekuju da učenici iznesu svoj doživljaj i razmišljanja o književnoumjetničkom djelu.

Drugi problem bio je ispitati smatraju li učitelji da njihov pristup obradi lektire potiče razvijanje čitateljskih kompetencija. Većina učitelja (79\%) dala je afirmativan odgovor. Treći problem istraživanja bio je ispitati na koji način učitelji motiviraju učenike za književnoumjetničko djelo. Najviše učitelja (53\%) izjasnilo se da usmenim putem motivira učenike za književnoumjetničko djelo, zatim igrom (18\%), njih 14\% motivira različitim načinima koji su svrstani u podskupinu Ostalo, vizualnim putem (6\%), postavljanjem problemske situacije (4\%), a 5\% učitelja nije se izjasnilo. Prevladava usmeni način motivacije, ali postupno počinju prodirati i drugi oblici.

Budući da je ipak riječ o subjektivnim dojmovima učitelja, ne možemo govoriti o sasvim pouzdanim rezultatima. Ono što možemo potvrditi temeljem prikupljenih podatka i analiziranih rezultata je da ispitani uzorak učitelja razredne ima razvijenu svijest o potrebi kvalitetnog i kreativnog pristupa obradi lektire. Donošenju preciznijih zaključaka značajno bi doprinijelo i ispitivanje stavova učenika. 


\section{LITERATURA}

Bežen, A. (2008). Metodika - znanost o poučavanju nastavnog predmeta. Zagreb: Profil.

Braš Roth, M. i sur. (2010). PISA 2009: Čitalačke kompetencije za život. Zagreb: Nacionalni centar za vanjsko vrednovanje znanja - PISA centar.

Bubić, A. (2015). Osnove statistike u društvenim i obrazovnim znanostima, Split: Filozofski fakultet Sveučilišta u Splitu.

Čudina-Obradović, M. (2014). Psihologija čitanja - od motivacije do razumijevanja. Zagreb: Golden marketing - Tehnička knjiga.

Grosman, M. (2010). U obranu čitanja: čitatelji i književnost u 21. stoljeću. Zagreb: Algoritam.

Lazzarich, M. (2017). Metodika Hrvatskoga jezika u razrednoj nastavi. Rijeka: Učiteljski fakultet u Rijeci.

Lučić-Mumlek, K. (2002). Lektira u razrednoj nastavi. Zagreb: Školska knjiga. MZOŠ (2006). Nastavni plan i program za osnovnu školu. Zagreb: GIDEON.

MZOŠ (2010). Nacionalni kurikulum za predškolski odgoj i obrazovanje te opće obvezno $i$ srednjoškolsko obrazovanje. <raspoloživo na: http://www.azoo.hr/index.php?option=com_content\&id=1227:nacionalniokvirni-kurikulum\&Itemid=486 > \{pristupljeno 12. lipnja 2018.

Peti-Stantić, A. (2009). Jezične igre za velike i male. Zagreb: Alfa.

Puljak, L. (2001). Metodički priručnik uz Moju početnicu za 1. razred osnovne škole. Zagreb: Znanje.

Puljak, L. (2007). „Psiholingvistički pogled na početno opismenjavanje“. Metodički ogledi 14 (1): 61-76.

Reić-Ercegovac, I., Jukić, T. (2008). „Suradničko učenje u razrednoj nastavi“. Život $i$ škola 20 (2/2008.)/ 56: 69-80. <raspoloživo na: https://hrcak.srce.hr/file/ $57969>$, \{pristupljeno 8. kolovoza 2018.

Rosandić, D. (1986). Metodika književnog odgoja i obrazovanja. Zagreb: Školska knjiga.

Rosandić, D. (2005). Metodika književnoga odgoja i obrazovanja: temeljci metodičkoknjiževne enciklopedije. Zagreb: Školska knjiga.

Težak, S. (1996). Teorija i praksa nastave hrvatskoga jezika 1. Zagreb: Školska knjiga.

UNESCO, (2004). The Plurality of Literacy and its Implications for Policies and Programmes: Position Paper. United Nations Educational, Scientific and Cultural Organization 7, <raspoloživo na: http://unesdoc.unesco.org/images/0013/001362/136246e.pdf>, \{pristupljeno 1. svibnja 2018.\} 
Ivana M. Odža

Jelena N. Mudrovčić

University of Split

Faculty of Philosophy

Department of Teacher Education

\title{
METHODICAL APPROACHES TO MANDATORY READING IN THE FIRST GRADE OF ELEMENTARY SCHOOL: A CHALLENGE FOR ENCOURAGING AND DEVELOPING READING COMPETENCES
}

\begin{abstract}
Summary
One of the basic tasks of Croatian language education in elementary school is to develop readers' habits. Since young people today read less and less and there is a general decline in the interest in reading books, mandatory reading has become a necessary means of familiarising students with reading. Teachers, through their methods and methodical approaches, can substantially influence students and their reading culture. The purpose of the paper is to contribute to the profession with the research into teachers' methodical approaches to mandatory reading classes in the first grade of elementary school, which includes 89 teachers of the Split-Dalmatia County and the City of Zagreb. The aim of the paper is to explore the teaching methods and methodical approaches to mandatory reading in the first grade of elementary school. A survey questionnaire was developed as a research tool that collected the data in accordance with the stated primary objective and research issues. The results of the research have shown that the teachers opt for more contemporary methodical approaches to encourage the development of reading competences. We cannot deem the results as utterly conclusive considering that the teachers'opinions reflect their subjective conclusions. We can, however, confirm, based on the collected data and analysed results, that the examined sample of elementary school teachers has developed an awareness regarding the quality and creative approach to mandatory reading classes. It would be interesting to extend this research and include the investigation of children's opinion regarding teachers' methodological approaches.
\end{abstract}

Keywords: Croatian language education, primary school education, mandatory reading, teachers' methodical approaches, reading competences.

Primljeno: 4. 9. 2018.

Prihvaćeno: 15. 10. 2018. 